Document downloaded from:

http://hdl.handle.net/10251/81122

This paper must be cited as:

Belso Martínez, JA.; Expósito Langa, M.; Tomas Miquel, JV. (2016). Knowledge network dynamics in clusters: past performance and absorptive capacity. Baltic Journal of Management. 11(3):310-327. doi:10.1108/BJM-02-2015-0044.

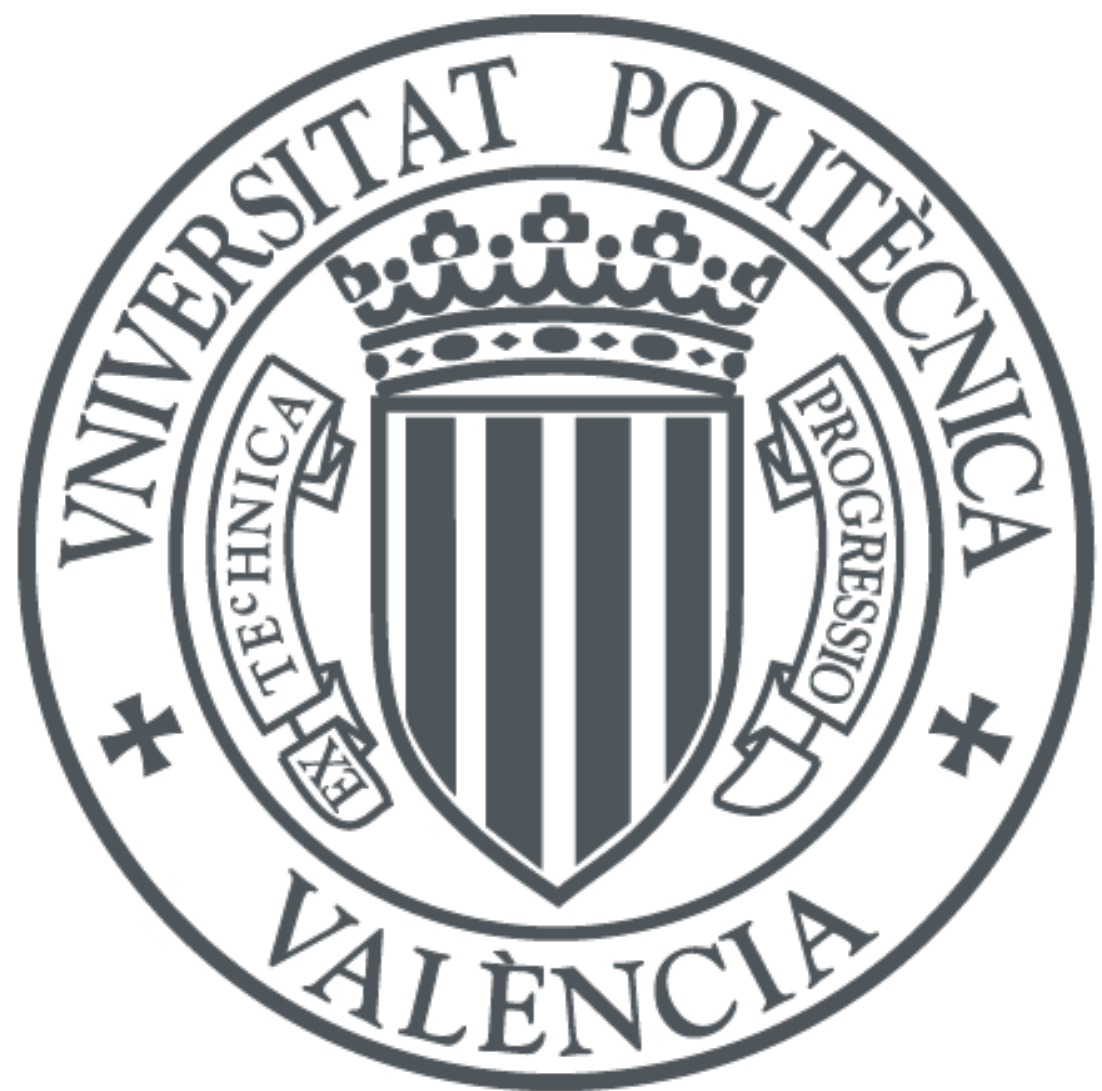

The final publication is available at

http://dx.doi.org/10.1108/BJM-02-2015-0044

Copyright Emerald

Additional Information 


\title{
KNOWLEDGE NETWORK DYNAMICS IN CLUSTERS: PAST PERFORMANCE AND ABSORPTIVE CAPACITY
}

\author{
José-Antonio Belso-Martínez \\ Universidad Miguel Hernández \\ Department of Economics and Finance \\ Manuel Expósito-Langa \\ Universitat Politècnica de València \\ Business Administration Department \\ José-Vicente Tomás-Miquel \\ Universitat Politècnica de València \\ Business Administration Department
}

\begin{abstract}
Purpose - The purpose of this paper is to explore the degree to which absorptive capacity and previous innovative performance affect network dynamics, specifically in the creation or destruction of inter-business relationships.

Design/methodology/approach - The empirical study has drawn on the data collected in an industrial cluster located in the Valencian Community in Spain. This population of firms allowed us to test various roles played by network endogenous forces, absorptive capacity and former performance in the creation and dissolution of inter-organisational linkages. We followed an evolutionary approach and applied network analysis techniques.
\end{abstract}

Findings - Empirical evidences suggest that absorptive capacity and previous innovative performance are predictors of inter-business relationships. Absorptive capacity affects the emergence of linkages in the technological network, due to the tacit nature of technological knowledge. On the other hand, previous innovative performance is an indicator to identify leaders companies. These companies tend to increase the reception of request for advice from local firms. Moreover, prestigious companies tend to be more selective in choosing collaborators.

Practical implications - This study helps researchers and managers better understand network dynamics. The generation of inter-organisational relationships in clusters can be determined by cognitive proximity and prestigious status in the network. These evidences are relevant in a mature cluster where knowledge is asymmetrically distributed.

Originality/value - Over the last few decades, studies on industrial clusters have evolved from the "canonical" standpoint. Nowadays, researchers usually take a more sophisticated and richer view of this reality, mainly as a consequence of the inclusion the proximity concept, intracluster heterogeneity and advanced analysis of overlapping between networks and territory. Thus, we try to add some empirical evidence along these lines.

Keywords: Industrial Cluster, Networks, Performance, Absorptive Capacity, Status

Article Classification: Research paper 


\section{Introduction}

Over the last few decades, there has been a great proliferation of papers on the creation, evolution and effects of business networks, based on their influence on the innovative performance of companies. Industrial clusters, which are an example of relational architecture limited to a specific geographical area, are no exception (e.g. Ibrahim et al., 2006; Pullen et al., 2009; Clauß, 2012). Although several papers have shed some light on what determines the formation of these relational structures, the genesis and changes in inter-organisational networks still require special attention. This is not so necessary for the endogenous mechanisms of the network per se (Rivera et al., 2010), but more so for the role of the attributes of actors involved and the consequences for the structure, or in their position (Lee, 2010).

Following an evolutionary approach (Nelson and Winter, 1982), relationships among businesses emerge, change or disappear partly due to the profile of the knowledge base, absorptive capacity or prestige of the actors involved. Changes brought about by the actors' profiles lead to variations in the whole of the global structure of the interorganisational network to which they belong. Several papers on industrial clusters have adopted this evolutionary view over the last decade (Bell, 2005; Giuliani and Bell, 2005; Boschma and Ter Wal, 2007; Giuliani, 2007; Morrison and Rabellotti; 2009, among others), and believe that, in these territorial systems, there is a cross-over among multiple networks where various actors interact, evolve and contribute to the development of a specific geographical context. In this spider web of networks, two are clearly identifiable - one of technological knowledge, and the other for business information. While mainly tacit knowledge about product and processes flows through the former, the latter contains more coded information relating to organisational or marketing aspects (Lissoni, 2001).

Recently, these evolutionary ideas have been enthusiastically adopted by scholars interested in the spatial dimension (Boschma and Frenken, 2010; Giuliani, 2013; Balland et al., 2013). Going beyond the usual emphasis on geographical proximity, the new perspective extends the set of pertinent factors for understanding the dynamics of inter-organisational relationships, and especially includes the actors' characteristics and gives a prominent role to Path Dependence. This recognises how certain contingent events trigger relevant behaviour. The relational dynamic tends to be reproduced even 
in the absence of the forces that originally enabled their creation, and there are certain features in the reproduction processes that prevent or hinder change.

Despite the efforts made in this area so far, in our view, there are still some issues that need further attention. Firstly, the recognition of the presence of multiple types of networks requires a specific study of the network dynamics in each context, highlighting the existing differences and similarities between them. Secondly, aspects such as the causal link between networks and innovation has received little attention (Harhoff et al., 2014), where most of the limited literature focus on the impact of the network on innovation, and understate the opposite impact of innovation on the network. Networks are extremely important for accessing knowledge, which when appropriately re-combined, leads to innovation. However, certain innovative past actions can function as signposts that later determine the relational dynamics (Ryall and Sorensen, 2007). Finally, although some papers concentrate on analysing the relevance of endogenous forces and the characteristics of companies belonging to the network (Balland, 2012; Balland et al, 2013; Giuliani, 2013, Cassi and Plunket, 2014; Ter Wal, 2014), empirical evidence is limited, due to complex methods or the difficulty in obtaining suitable databases ${ }^{1}$.

Due to this research gap and using the above-mentioned evolutionary insights, our paper sheds light on the effects caused by company characteristics and the endogenous forces of the network on the relational dynamic of companies in two types of networks, i.e. technological and business networks, thus attempting to shed new empirical evidence on the dynamic evolution of the cluster. We will observe in particular the influence of innovative past performance and absorptive capacity on the creation or destruction of inter-business relationships in the two networks analysed, additionally exploring if these explanatory variables have different effects in both scenarios. The objective will be achieved by using an exponential random graph model (ERGM) and data from 36 companies belonging to the Spanish foodstuffs cluster in Xixona.

Following this introduction, the second section will give a brief presentation of the literature and the hypothesis. The third section describes the main characteristics of the cluster analysed. The fourth section contains aspects on methodology, econometric 
techniques used and the outcomes. The research ends with the main conclusions and implications.

\section{Literature and Hypotheses}

Well-known papers based on Marshall's principles have, for years, emphasised the importance of geographical location as one of the driving forces in competition among businesses (Saxenian, 1994; Audretsch and Feldman, 1996; Capello and Faggian, 2005, among others). Geographical proximity promotes interaction and an exchange of knowledge among actors and boosts innovative performance.

Recent papers show that mere geographical proximity is neither a necessary nor a sufficient condition for inter-organisational learning and successful knowledge transfers (Boschma, 2005). The benefits arising from locating in a cluster are not due to unplanned access to knowledge "floating in the air", but to selective interaction and informal contacts occurring among the actors making up the knowledge networks (Bell, 2005; Giuliani, 2007).

Taking part in any way in these knowledge networks is not automatic or homogeneous for firms located in clusters. For example, some "micro" characteristics determine access and the degree to which companies benefit from external resources, and this affects the conformation of the entire network (Boschma and Ter Wal, 2007). Put another way, heterogeneity at intra-cluster level affects the systemic structure, the way in which knowledge is transferred within the grouping, and how it is absorbed by local actors.

Basically, inter-organisational networks enable companies to solve problems jointly, provide access to essential resources (Zaheer and Bell, 2005) or share knowledge. A novel combination of these knowledge or technological inputs acquired externally enables the company to design new solutions to issues relating to product launches, production processes, or organisational and marketing strategies (Nelson and winter, 1982). Hence, the desire to innovate is the driving force behind companies searching for and setting up new collaborative projects within the cluster boundaries. 
The scientific community has little doubt of the importance of networks to innovation (Fornhal et al., 2011). Companies set up relationships that furnish knowledge required to innovate, but aspire to minimise the effort required for this. Indicators, such as prestige and status, help firms to diagnose partners' potentialities or their stock of internal resources (e.g. the absorptive capacity). In this vein, a successful innovation trajectory attracts new partners, while a limited portfolio of innovation results raises barriers and leads to isolation.

\section{Hypotheses}

While information simply represents a flow of messages, knowledge is created and organized by the flow of information and also through a dynamic social process of mutual exchange and shared learning (Howells, 2012). The characteristics of knowledge shape the ways in which it can be absorbed by organisations. Knowledge can either be explicit (also called codified) or tacit (Polanyi, 1966). Explicit knowledge is expressed and communicated in formal and systematic form, while tacit knowledge is hard to codify and transfer.

The absorptive capacity, defined as the ability to recognize the value of new information, assimilate it and apply it to commercial ends, is essential to successful knowledge transfer and acquisition (Cohen and Levinthal, 1990). A minimum threshold of resources and this particular capability are a "sine qua non" condition for compressing, transforming and disseminating knowledge (Caragliu and Nijkamp, 2014). Once a certain level of this dynamic capability exists, firms can better integrate external knowledge into its own innovation practices, speeding up the creation of new products or processes (Teece, 2007).

Due to its cumulative and path dependence nature, firms with solid related knowledge and experience present higher levels of absorptive capacity. Consequently, it may be easier for them to assimilate complex knowledge and overcome the difficulties related to the transmission of tacit knowledge such as asymmetric cognitive schemas or limited face-to-face interactions (Torre, 2008). In this vein, Mowery and Oxley (1995) specifically consider absorptive capacity as a broad set of skills through which an organisation deals with the tacit component of the technical knowledge. 
Clusters are conformations where multiple networks overlap (Bell, 2005), and local SMEs obtain significant benefits from the access to this set of explicit and tacit knowledge networks (Keeble and Wilkinson, 2000). Particularly, inter-organisational configurations through which technical knowledge and business information are shared, have been of particular recent interest. In this vein, Giuliani (2007) shows how the formation of these networks is driven by different underlying motivations. Firms with solid internal resources and the capability to absorb complex knowledge, are more prone to exchange innovation related knowledge with other cluster units. However, linkages formed for a business related matter are associated with the pervasive pattern of business interaction in clusters. Co-location and not firms resources and capabilities seems the key driver of business matter interactions. Therefore, it can be stated:

$\mathrm{H}_{1}$ : Absorptive Capacity matters more when establishing relationships in the technological knowledge network than in the business information network.

Former performance influences the way in which a company evolves, makes decisions and adapts to the environment (Miller, 1994). Additionally, past performance can be used by others actors to identify future alliances (Fombrun and Shanley, 1990). Considering the results from past performance as a reputation status (Shapiro, 1983), an actor's record on innovation is a pertinent indicator for the other members of the network (Gould, 2002) as it presupposes solid knowledge and internal resources (Van der Vegt et al. 2006). More recently, in connection with the concept of reputation status, Chandler et al. (2013) show how status and prestige influence firms' relational dynamics, although with different levels of intensity. In addition, Giuliani (2013) has studied status as a valid and time-saving criterion for deciding which firms to approach for advice.

A strong reputation based on past innovation performance, encourages local units to cooperate with successful companies (Cross and Cummings, 2004; Lee, 2010), and there seems to emerge a correlation between the creation of linkages and the innovation background (Baum et al., 2005). In this manner, status effects may drive the formation of new ties; firms guided by status when searching for technical advice will target prominent firms (Giuliani, 2013). 
In this sense, actors with low status may try to connect with others with high status in order to bring higher returns (Stuart et al., 1999). In consequence, the best-positioned actors in the network rapidly gain reputation because they are frequently cited, which contributes to their aura (Giuliani, 2013). Whenever identification of these leaders is easily obtained via observation or local broadcasting, the actors reduce their search costs and uncertainty by addressing them directly when establishing new collaborations (Ejermo and Karlsson, 2006). As a result, highly reputed actors may be considered more valuable and therefore more popular exchange partners (Ebbers and Wijnberg, 2010) because these relationships provide valuable resources and generate spillover effects by improving the status of the weaker companies (Podolny, 1993).

On the other hand, firms exhibiting limited innovation records have little to offer to prestigious collaborators in order to counteract the high costs involved in cultivating new business relationships. Furthermore, if too much interaction with companies with a poor innovation profile is undertaken, leader's reputation status may be damaged. Consequently, actors with high status do not have an incentive to affiliate themselves with others with low status, not only because they would threaten the value of their own status (Benjamin and Podolny, 1999), but also because the risk of opportunistic behaviour (Ebbers and Wijnberg, 2010).

Therefore, the following hypotheses can be set forth:

$\mathrm{H}_{2}$ : A successful innovation trajectory affects the creation of links between companies.

$\mathrm{H}_{2 \mathrm{a}}$ : A successful innovation trajectory has a negative effect on openness to proposing new collaborations.

$\mathrm{H}_{2 \mathrm{~b}}$ : A successful innovation trajectory has a positive effect on openness to receiving proposals for new collaborations.

\section{Empirical study}

The foodstuffs cluster in Xixona

According to the National Institute of Statistics, $77 \%$ of the 441 establishments comprising the Spanish confectionery industry elaborate products without chocolate or cocoa (including nougats and marzipan). Although there are some large firms, $70 \%$ of 
the local companies have less than 20 employees, and many are family businesses. The geographical distribution of the industry is highly concentrated in certain regions (Catalonia) and cities (Estepa and Toledo). Among the cities, the production of turrón (a particular type of nougat) and Christmas confectionery in Xixona (Valencian Community) is a paradigmatic case.

This small Valencian town of 8,000 inhabitants has benefited of the characteristics of its climate to manufacture turrón (see Figure 1). Since the XVth century, artisans have been mixing toasted almonds, honey, eggs and sugar to make this traditional confectionery. Except for the diet versions, the latest flavours and textures date from over one hundred years ago. The 20th century saw a period of technological modernisation and mechanisation leading to the construction of factories to cater for the needs of large-scale commercial production, although it is true that artisan techniques still persist in some micro-businesses. During the 1990 s, problems relating to new trends in consumption, the availability and price of the inputs, difficulty in innovating and internationalisation have been detrimental to the cluster's development. In spite of the above, and helped by other food products (especially ice-cream), nougat and Christmas confectionery remain the driving force of the local economy in Xixona.

Although Boix and Galletto (2006) identified the area as an industrial cluster, using ISTAT methods, there is still argument over various systemic aspects. In particular, March-Chordá et al. (2007) questioned aspects relating to cohesion and cooperation dynamics. In addition, the prevalence of heterogeneous behaviour at a strategic level fragments the business community in terms of strategic and competitive advantages (especially corporations versus SMEs). In short, it seems that the nougat manufacturers take advantage of their location, but some certain shortcomings make it difficult for them to benefit from the many technical and commercial synergies.

Several organisations around the cluster support local manufacturers. The Nougat Business Association (TDC) founded in 1997 looks after the interests of the vast majority of local producers. It is there mainly to represent, coordinate, promote, train and advise its members. TDC promotes a culture of quality via seminars and takes part in projects designed to improve the image and global competitiveness of the sector (food safety, technology, design and advertising, marketing, on-line training, 
information, among others). Its work was fundamental in obtaining the "Turrón de Xixona y Alicante" denomination of origin certificate in 1991. This award provides great benefits for sales, based on guaranteed quality of the product. Since then, the Regulatory Board has supervised maintenance of the original standards of quality and protects against imitations. Nowadays, 21 companies making $38 \%$ of national sales and $42 \%$ of exports sell their products under this umbrella. TDC and the Regulatory Board have promoted cooperation dynamics in pursuit of new techniques and innovative processes, product renewal and the start of new sales practices.

The three universities near to the cluster (the Polytechnic University of Valencia, University of Alicante and Miguel Hernández University) have not contributed suitable knowledge and have remained aloof from the real situation in the sector. The Food technological institute (AINIA), created in 1987, has also failed to develop a significant relationship with the cluster. In spite of the potential of this organisation, which belongs to the regional network of technological centres, the low relevance of the Xixona cluster within the whole agro-food industry limits the attention paid to specific local challenges in favour of the interest of the remaining 900 members.

\section{Questionnaire}

Data for this study were gathered in Xixona during the second half of 2011. Following a procedure similar to that described in Giuliani (2013), in a first stage and prior to the main field work, personal interviews were held with key manufacturers and institutions to obtain information on several aspects of the industry and cluster. The information acquired and the literature review were used to design the questionnaire and discuss the final outcomes. Following certain modifications derived from a pre-test made with representatives of the academic and business community, the final questionnaire was ready to be submitted to cluster firms.

The profile of the data requested for our research and the characteristics of the population led us to choose the Roster-Recall method as the most appropriate for identifying relationships among companies (Giuliani and Bell, 2005; Boschma and Ter Wal, 2007; Morrison and Rabellotti, 2009; Giuliani, 2013). Each interviewee assessed their relationships with all local manufacturers and local suppliers from whom they received or transferred technical or market advice. In addition, the respondents were 
invited to add more companies (competitors, customers or suppliers) with whom they had contact but did not appear on the list.

\section{Data collection}

The 36 manufacturers and local suppliers obtained from the databases provided by the TDC and the Regulatory Board answered the questionnaire. Peer Debriefing confirmed that only a few artisans (usually self-employed) had remained outside the process, and all significant actors had been interviewed. In the end, 24 manufacturers of confectionery products and 12 suppliers accepted the invitation to collaborate, representing a response rate of $100 \%$ suitable for a whole network approach (Wasserman and Faust, 1994).

A technician with experience in innovation programmes who had worked in business associations held the 40 or 50-minute interviews with company owners or top managers.

In our opinion, the interviewer's profile decisively contributed to the robustness and reliability of the field work. The relational data collected reflected the relevance of each inter-organisational contact depending on respondent's perception. Both on technical and business aspects, questions rated the existence and importance of the different contacts from 0-3. The respective questions read as follows: a) From which of the firms on the list have you regularly asked for technical/business information during the last three years?; b) From which of the firms on the list have you regularly received requests for technical/business information during the last three years? .

Using the Harmon test, common method bias was discarded once the exploratory factor analysis including all variables did not identified one single factor accumulating most of the variance. Table 1 gives the characteristics for the company: size, decade in which it was started, legal structure and international operations. In addition, it also gives information on membership of local organisations and the main business activity. Bias was ruled out.

\section{$<$ Insert table 1 about here $>$}

Variables 


\section{Dependent variable}

We now turn to an analysis of interaction among the firms included in the analysis. To such end, the data are organised into a relational matrix, where each column $i$ and each row $\mathrm{j}$ represent a company, and the cell input is the value that company $\mathrm{i}$ places on their relationship with company $\mathrm{j}$. This creates a directional or asymmetrical matrix, as the value perceived by company $\mathrm{i}$ does not necessarily match the value perceived by company j. Due to the method and software used, each cell conforming to the relational matrix has to be binary (take value 0 or 1 ). Therefore, we condensed the perceived relevance for each relationship into a dummy variable and coded values 2 and 3 as 1 , and 0 for the remaining. We skipped the lowest value in order to ensure that only relevant interactions were used in the analysis.

\section{Explanatory variables}

The first of the hypotheses presented stated that the companies' absorptive capacity was more significant for creating relationships in the technological knowledge network than the business one. To test this, we constructed a variable according to previous papers (Giuliani and Bell, 2005; Giuliani, 2013) that had related absorptive capacity to prior experience and training levels. A factor analysis was used to condense information obtained from 4 items that included the percentage of employees with higher education and experience prior to 2005 and 2010, respectively. The value of the Cronbach's Alpha was .811. Moreover, the Kaiser-Meyer-Olkin (KMO) measurement was greater than .5 $(\mathrm{KMO}=.747)$. Therefore, it was appropriate to proceed with a factor analysis (Coakes and Steed, 2001).

In order to contrast compliance of the second hypothesis, we set up another independent variable that condenses information on ten items relating to product innovation, processes, organisation and marketing during the period 2003-2005. Initially, four factors were created, one for each type of innovation (Cronbach's Alpha >.7 and KMO $>.5$ ). Once obtained, the four factors were put together in a single global innovation indicator tested with a second-order factor analysis model (Bentler, 1993; Jöreskog and Sorbom, 1996). Here it was assumed that if the constructs were related to each other, they would all load on a higher order factor nominally called innovation. This procedure has been adapted from previous contributions such as Wang and Ahmed (2004), Alegre and Chiva (2008) or Jiménez-Jiménez and Sanz-Valle (2011). To gain a more refined 
evaluation of our hypothesis, we made a separate observation of the extent to which the company would seek advice (ego effect) or provide it (alter effect), depending on the previous innovation trajectory.

More variables were used to check whether other characteristics of the companies, namely age and position on the cluster's value system, affected the creation of linkages. We measured the first characteristic using the square root of the number of years since it was founded. The business activity was entered into the model using a binary variable at a value of 0 when it was the manufacturer, and a value of 1 if it was a supplier. Table 2 shows the correlations between the independent variables.

$<$ Insert table 2 about here $>$

Three statistics allow us to control the structural effects or "endogenous forces" of the network: the number of network nodes, which coincides with the density in the case of asymmetric networks; reciprocity between partners, or if there is a tendency to ask for advice from collaborators to whom support is normally given; and finally, transitivity is the last "endogenous force" included in the model. The statistic captures the tendency towards closed triads, reflecting whether the firms cooperating with a common third are more likely to become partners ("friends of friends become friends"). Figure 2 provides a brief description and a graphic representation of the specifications used throughout this research (Hunter, 2007; Morris et al., 2008).

$<$ Insert figure 1 about here $>$

\section{Statistical analysis and results}

The architecture of the two networks is similar and overlaps considerably (see Table 3 ). Both of them are compact structures, with the technological network being slightly denser $(2.4 \%)$ and more central (11\%). Transitivity is more frequent in the business information network, while reciprocal relationships are noticeably higher in the technological knowledge one. Graphic representation of both networks supports the compactness mentioned. As can be seen in figure 2, the centre of the technological network is usually taken up by the larger (diameter of the sphere) suppliers (red). Manufacturers (blue) are more central in the business network. 
$<$ Insert Table 3 about here $>$

Exponential random graph models are mathematical tools used to study complex systems whose exact structures are too complicated to be given in detail. These types of models inform, from a series of cross-sectional data, how far, the network observed differs from a completely random network. As the observed network responds to a stochastic process, the model formulated to explain the behaviour of the network will propose a number of hypotheses based on theoretical premises for the specific stochastic process (Robbins et al., 2007). The final outcome provides a wide variety of network effects, also the parameters obtained from an estimation of maximum verisimilitude and Montecarlo chain methods (MCCM).

In our case, these statistical tools help to explain the formation of linkages between firms via dyadic dependent and independent processes. In the dependent ones, the status of a dyad depends stochastically on the status of the other dyads. On the other hand, in independent dyadic processes, the status of the dyad depends on the attributes of the two nodes (Handcock et al., 2008). Recently, Broekel and Hartog (2011) showed the validity of this type of model when explaining the phenomenon of inter-organisational relationships.

$<$ Insert figure 2 about here $>$

The models displayed in table 4 support our expectations. Within the technological knowledge network, the absorptive capacity provides a highly significant positive effect ( $p$-value $<.05)$. However, the same variable has no statistical significance in the business information network. The combination of both results provides support for the first hypotheses $\left(\mathrm{H}_{1}\right)$. The significance levels of variables relating to previous innovative performance support $\mathrm{H}_{2}$. Furthermore, Innovation (Ego) has a negative effect on both the technological knowledge network $(\mathrm{p}$-value $<.05)$ and the business information network ( $\mathrm{p}$-value $<.01$ ), corroborating our expectations again according to $\mathrm{H}_{2 \mathrm{a}}$. In the same vein, Innovation (Alter effect) promotes generation of relationships in both networks ( $\mathrm{p}$-value $<.01$ ), endorsing $\mathrm{H}_{2 \mathrm{~b}}$. 
$<$ Insert table 4 about here $>$

The sensitivity diagnosis made on the models in table 4 supports the robustness of our results. The auto-correlation coefficients among various intervals are close to 0 , with the exception of the initial one, which always takes the value 1. Moreover, Gewerke statistics, which are relatively comparable to a $\mathrm{Z}$ statistic, give no significant return for a p-value $<.1$. Although they may provide certain information on the goodness of fit of the models, the AIC and BIC measurements were not taken into account, due to the dependency of the sampling data (Hunter et al., 2008). Instead, we evaluate the goodness of fit of the models by comparing the observed networks with a set of simulated networks based on certain statistics (Hunter et al., 2008). To obtain a good reality check, all network statistics in the model are used as a basis for comparison between the technical and business networks and a series of 100 randomly generated networks obtained from the fitted models (Butts, 2011). Results reveal an acceptable fit in both the technical and business models, as the observed statistics are near the sample median (.5).

\section{Conclusions and implications}

This work was based on the expected complex relationships between company characteristics, network typology and endogenous forces, and firm's relational dynamics in a territorial cluster. We assumed that absorptive capacity had a different level effect on the creation of inter-business relationships in the technological and the business network. On the other hand, we also investigated the causal relationship between innovation past trajectory and network dynamics. Our research has attempted to shed new empirical evidence on the dynamic evolution of the cluster. In our view our paper contributes to the literature in several different ways.

Firstly, while the absorptive capacity is a key factor in establishing new relationships in the technological knowledge network, it does not significantly affect the emergence of linkages in our business information network. The tacit profile of technological knowledge requires a minimum threshold of resources and capabilities in order to be properly internalised and disseminated within the organisation. In contrast, the codified knowledge shared in the business network smoothes its indigenisation, reducing the relevance of the absorptive capacity when forming links. From a meso-level 
perspective, we may presume a relative proliferation and easy diffusion of business information within the cluster boundaries, especially, when compared to the technological knowledge which seems more selectively accessed and disseminated.

The implication of this finding seems evident: a minimal amount of this dynamic capability is needed to engage in the technological knowledge network. Companies with a low absorptive capacity tend to be left on the side-lines and face greater difficulties in accessing valuable technical knowledge. Company managers must be aware of the need to cultivate this skill as a key factor for entering a select club able to breathe into the organisation the technical knowledge required for innovation. Also, policy makers must be aware of this finding. Integrating companies with fewer resources and capabilities requires that they enhance their absorptive capacity, and promote permeability of technical knowledge through programmes led by local organisations. Such actions not only boost innovation in more fragile firms, but also foster cluster's atmosphere of innovation by promoting a generalized dissemination of knowledge and better integration of weaker units. The limited absorptive capacity required to digest business information allows policy makers and practitioners and company managers to moderate efforts when just aspiring to capture this codified knowledge. Resources should tilt more towards the technological field to achieve a better assignment and greater efficiency. Our results for the technological network are in line with previous research that highlights the relevance of the firm's absorptive capacity to explain the network dynamics in a cluster (Boschma et al., 2011; Giuliani, 2013). However, unlike these previous works, in our contribution we go one step further by also comparing this result in the context of the business network. Consequently, this study can be taken as a complement to the existing research outcomes on the relationship between absorptive capacity and network dynamics.

Secondly, previous innovation performance is an element to bear in mind when analysing the creation and dissolution of relationships in an agrifood cluster. When there is close geographical proximity, information constantly flows between local actors. For example, through casual conversations or coffee meetings, owners and top managers share insights or views on how the market is evolving or competitors are 
faring. In this respect, information acquired by co-located firms over time determines the network dynamics.

Our analysis of the impact of the innovation trajectory highlights the greater complexity of the positive effect on generating the relationships initially expected. The negative sign of the Ego effect implies that, the better the previous performance, the less likelihood there is of firms seeking information from third parties, while the positive sign achieved by the Alter effect reveals that higher innovation is followed by an increase in the reception of requests for advice from local firms. To the extent that the innovative trajectory can be interpreted as a basic benchmark of the firms' prestige and status, such evidence certainly seems rather consistent and justifiable. Clustered firms showing solid record of innovation occupy prestigious positions and attract the interest of other co-located units. They are surrounded by an aura that creates expectations among the less innovative firms, due to the potential benefits in terms of access to crucial knowledge, relative improvement in their own prestige or reduction of costs associated with setting up fruitful relationships. On the other hand, from the point of view of the top companies, establishing links with less innovative firms may damage their advantageous position and jeopardize their resources in building relationships with limited returns. Therefore, companies in leading positions tend to be selective when choosing collaborators. All these results are consistent with those contributions which study the importance of status to shape network dynamics (among others, Boschma et al., 2011; Balland, 2012; Giuliani, 2013; Balland et al., 2014). Nevertheless our research in our opinion, provides a novel approach of the status from the point of view of the innovation past trajectory which enriches the perspective of this construct and emphasizes the possibility that innovation is not just a result of networking processes but also it can act as an explanatory variable of the network dynamics. Furthermore, our study addresses the explanatory capacity of innovation to explain not just the reception of requests for advice from local firms (alter effect) as studied by past research, but also the establishment of new ties to obtain information from third parties (ego effect). This novel approach allowed us to figure out how a firm's successful innovation trajectory divergently influences network dynamics. On one side, it increases the reception of request for advice but reduces the possibility to establish new ties with third parties. 
The implications are significant from the management perspective. The ability to provide valuable knowledge to local firms shapes the access to key actors and the effects of an overflow of prestige that this would involve. Company managers aspiring to benefit from the creation of ties with local leaders must offer value inputs in order to awaken their interest (Harmaakorpi and Niukkanen, 2007). In spite of their impressive trajectory, the most innovative actors should keep scanning the local environment in search of potential partners and fruitful collaborations in order to remain a step ahead of the other local leaders. Policy makers must be aware that removing barriers to establishing these asymmetrical relationships can improve the ability to innovate and prestige of the cluster as a whole. It seems advisable to deploy measures that minimise the risks and costs for leading companies, or widen the knowledge base of the less innovative, thus helping to establish beneficial cooperation agreements.

Thirdly, the results confirm our expectations on the evolutionary nature of the genesis and relational dynamics in the clusters, as well as the advantages of random graph models when assessing the influence of structural forces of the intra-cluster networks and the characteristics of the nodes comprising them. The negative coefficient of global density is common in networks generated through social processes, and shows that this type of structure is less dense than exponential random networks (Broekel and Hartog, 2011). In addition, the significance attained by the phenomenon of transitivity points out a tendency for two indirectly connected firms to directly co-operate. So, the creation of closed triads is a driving force in forming the network, since new ties emerge. Furthermore, from a systemic point of view, this mechanism acts as a powerful instrument of social control, by reducing potential opportunist behaviour and reinforcing an atmosphere of cooperation. Finally, reciprocity is not a relevant mechanism for the birth of relationships within the cluster. In line with Ahuja et al. (2012), this result suggests that the effects of obligations incurred or sense of commitment, the reciprocity dynamics, may weaken over time. The thrust generated through pre-existent relationships vanishes, and the effect of former systemic structures in the current relational reality changes. Managers and policy makers must be aware of the advisability of cultivating traditional relationships and the dynamism of network structures that have been present for a long time. If not, the high costs and scant benefits arising from these poorer relationships will lead to the decline of the network. 
This paper is not exempt from certain limitations. Although the agrifood cluster analysed represents a paradigm case in the Spanish context, its particular features pertaining to the product, production process, limited innovative actions and advanced position in the life cycle must not be forgotten when extrapolating results. On the other hand, the particular conditions of the Xixona's confectionery industry may have also influenced the results obtained. This is especially relevant for the activities developed by local and regional associations and research institutes. Institutions and external agents through research projects and other activities can enhance collaboration and knowledge exchange between firms with different profiles and internal capabilities and so influence the pattern of network dynamics. As we have previously stated, the efforts made by cluster and regional institutions in order to promote and stimulate Xixona's confectionery industry have been limited and just reduced to the activities developed by the Nougat Business Association and the regulatory board. Neither nearby universities nor regional technological institutes as AINIA have significantly been involved in cluster's promotion and modernization. This situation could have facilitated the results obtained in this research. However, in other contexts where the influence of institutions and third parties are more relevant, the pattern of network dynamics and consequently our results may differ. Therefore, we must certainly make further studies of business clusters with a different profile to enable the trends observed to be corroborated. Although we have controlled the existence of bias, data were based on perceptions of top managers and business owners. Future research must try to corroborate the results through non-subjective indicators. Finally, the methodology used allows speculation on the inclusion of new business characteristics that help to achieve a more complete picture of the relational phenomenon in specific geographical areas. Extra-cluster connections (Bathelt et al., 2004) and the different proximity dimensions (Boschma, 2005) should be particularly addressed.

\section{Bibliography}

Ahuja, G., Soda, G. and Zaheer, A. (2012), "The genesis and dynamics of organizational networks", Organization Science, Vol. 23 No. 2, pp. 434-448.

Alegre, J. and Chiva, R. (2008), "Assessing the impact of organizational learning capability on product innovation performance: An empirial test", Technovation, Vol. 28 No. 6, pp. 315-326. 
Audretsch, D. and Feldman, P. (1996), "R\&D spillovers and the geography of innovation and production", American Economic Review, Vol. 86 No. 3, pp. 630-640.

Balland, P. (2012) "Proximity and the Evolution of Collaboration Networks: Evidence from Research and Development Projects within the Global Navigation Satellite System (GNSS) Industry", Regional Studies, Vol. 46 No. 6, pp. 741-756.

Balland, P., Belso-Martínez, J.A. and Morrison, A. (2014), "The Dynamics of Technical and Business Networks in Industrial Clusters: Embeddedness, status or proximity?", Papers in Evolutionary Economic Geography, No. 14.12, Utrecht University.

Balland, P., Boschma, R. and Frenken, K. (2012), "Proximity and innovation networks: An evolutionary approach, in Cooke, P. (Ed.), Re-framing Regional Development: Evolution, Innovation and Transition, Routledge, London/New York, pp. 186-200.

Balland, P., de Vaan, M. and Boschma, R. (2013), "The dynamics of interfirm networks along the industry life cycle: The case of the global video game industry, 1987-2007", Journal of Economic Geography, Vol. 13 No. 5, pp. 741-765.

Bathelt, H., Malmberg, A. and Maskell, P. (2004), "Clusters and knowledge: Local buzz, global pipelines and the process of knowledge creation", Progress in Human Geography, Vol. 28 No. 1, pp. 31-56.

Baum, J., Rowley, T., Shipilov, A. and Chuang, Y. (2005), "Dancing with strangers: aspiration performance and the search for underwriting syndicate partners", Administrative Science Quarterly, Vol. 50 No. 4, pp. 536-575.

Bell, G.G. (2005), "Research notes and commentaries: Clusters, networks, and firm innovativeness", Strategic Management Journal, Vol. 26 No. 3, pp. 287-295.

Benjamin, B.A. and Podolny, J.M. (1999), "Status, Quality and Social Order in the California Wine Industry", Administrative Science Quarterly, Vol. 44 No. 3, pp. 563589.

Bentler, P.M. (1993), EQS. Structural Equations Program Manual, BMDP Statistical Software Inc., Los Angeles.

Boix, R. and Galletto, V. (2006), "Sistemas locales de trabajo y distritos Industriales marshallianos en España", Economía Industrial, Vol. 359, pp. 165-84.

Boschma, R. (2005), "Proximity and innovation: A critical assessment", Regional Studies, Vol. 39 No. 1, pp. 61-74.

Boschma, R., Balland, P. A. and Kogler, D. (2011), "A relational approach to knowledge spillovers in biotech. Network structures as drivers of inter-organizational citation patterns", Papers in Evolutionary Economic Geography, No. 11.20. Utrecht University, Section of Economic Geography.

Boschma, R. and Frenken, K. (2010), "The spatial evolution of innovation networks. 
Aproximity perspective", in Boschma, R. and Martin, R. (Eds.), Handbook on Evolutionary Economic Geography, Edward Elgar, Cheltenham, pp. 120-135.

Boschma, R. and Ter Wal, A. (2007), "Knowledge networks and innovative performance in an industrial district: the case of a footwear district in the South of Italy", Industry and Innovation, Vol. 14 No. 2, pp. 177-199.

Broekel, T. and Hartog, M. (2011), "Explaining the structure of inter-organizational networks using exponential random graph models: does proximity matter?", Papers in Evolutionary Economic Geography, \#11.07.

Butts, C. (2011): Exponential random graph models for social networks. Simulation and model assessment. 4th Annual Political Networks Conference and Workshops, University of Michigan. Michigan: Ann Arbor. June 14-18

Capello, R. and Faggian, A. (2005), "Collective learning and relational capital in local innovation process", Regional Studies, Vol. 39 No. 1, pp. 75-87.

Caragliu, A. and Nijkamp, P. (2014), "Cognitive capital and islands of innovation: the Lucas growth model from a regional perspective", Regional Studies, Vol, 48 No. 4, pp. 624-645.

Cassi, L. and Plunket, A. (2014), "Proximity, network formation and inventive performance: in search of the proximity paradox", The Annals of Regional Science, Vol. 53 No. 2, pp. 395-422.

Chandler, D., Haunschild, P. and Beckman, C. (2013), "The effects of firm reputation and status on interorganizational network structure", Strategic Organization, Vol. 11 No. 3, pp. 217-244.

Coakes, S. and Steed, I. (2001), SPSS Analysis Without Anguish, Version 10.0, John Wiley, Sydney.

Cohen, W. and Levinthal, D. (1990), "Absorptive capacity: A new perspective on learning and innovation", Administrative Science Quarterly, Vol. 35 No. 1, pp. 128-153.

Clauß, T. (2012), "The Influence of the Type of Relationship on the Generation of Innovations in Buyer-Supplier Collaborations", Creativity and Innovation Management, Vol. 21 No. 4, pp. 388-411.

Cross, R. and Cummings, J. (2004), "Tie and network correlates of individual performance in knowledge-intensive work", Academy of management Journal, Vol. 47 No. 6, pp. 928-937.

Ebbers, J.J. and Wijnberg, N.M. (2010), "Disentangling the effects of reputation and network position on the evolution of alliance networks", Strategic Organization, Vol. 8 No. 3, pp. 255-275.

Ejermo, O. and Karlsson, C. (2006), "Interregional inventor networks as studied by patent coinventorships", Research Policy, Vol. 35 No. 3, pp. 412-430. 
Fombrun, C. and Shanley, M. (1990), "What's in a Name? Reputation Building and Corporate Strategy”, Academy of Management Journal, Vol. 33 No. 2, pp. 233-258.

Fornahl, D., Broekel, T. and Boschma, R. (2011), "What drives patent performance of German biotech firms? The impact of R\&D subsidies, knowledge networks and their location”, Papers in Regional Science, Vol. 90 No. 2, pp. 395-418.

Giuliani, E. (2007). The selective nature of knowledge networks in clusters: evidence from the wine industry. Journal of Economic Geography, Vol. 7, pp. 139-168.

Giuliani, E. (2013), "Network dynamics in regional clusters: Evidence from Chile", Research Policy, Vol. 42 No. 8, pp. 1406-1419.

Giuliani, E. and Bell, M. (2005), "The micro-determinants of meso-level learning and innovation: Evidence from a Chilean wine cluster", Research Policy, Vol. 34 No. 1, pp. 47-68.

Gould, R. (2002), "The origin of status hierarchies: A formal theory and empirical test", American Journal of Sociology, Vol. 107 No. 5, pp. 1143-1178.

Handcock, M., Hunter, D., Butts, C., Goodreau, S. and Morris, M. (2008), "Statnet: Software tools for the representation, visualization, analysis and simulation of network data", Journal of Statistical Software, Vol. 24 No. 1, pp. 1-11.

Harhoff, D., Mueller, E. and Van Reenen, J. (2012), "What are the channels for technology sourcing? Panel data evidence from German companies", Journal of Economics \& Management Strategy, Vol. 23 No. 1, pp. 204-224.

Harmaakorpi, V. and Niukkanen, H. (2007), "Leadership in different kinds of regional development networks", Baltic Journal of Management, Vol. 2 No. 1, pp. 80-96.

Howells, J. (2012), "The geography of knowledge: never so close but never so far apart”, Journal of Economic Geography, Vol. 12 No. 5, pp. 1003-1020.

Hunter, D. (2007), "Curved exponential family models for social networks", Social Networks, Vol. 29 No. 2, pp. 216-230.

Hunter, D., Goodreau, S. and Handcock, M. (2008), "Goodness of fit of social network models", Journal of the American Statistical Association, Vol. 103 No. 481, pp. 248258.

Jiménez-Jiménez, D. and Sanz-Valle, R. (2011), "Innovation, organizational learning, and performance", Journal of Business Research, Vol. 64 No. 4, pp. 408-417.

Jöreskog, K.G. and Sorbom, D. (1996), LISREL 8: User's Reference Guide, Scientific Software International, London.

Keeble, D. and Wilkinson, F. (2000), "High technology SMES, regional clustering and collective learning: an overview", in Keeble, D. and Wilkinson, F. (Eds.), High- 
Technology Clusters, Networking and Collective Learning in Europe, Ashgate, Aldershot.

Lee, J. (2010), "Heterogeneity, brokerage and innovative performance: endogenous Formation of collaborative inventor networks", Organization Science, Vol. 21 No. 4, pp. 804-822.

Lissoni, F. (2001), "Knowledge codification and the geography of innovation: The case of Brescia mechanical cluster", Research Policy, Vol. 30 No. 9, pp. 1479-1500.

March-Chordá, I., Adame-Sánchez, C. and Escrig-Tena, A. (2007), "Aplicación de un modelo de caracterización de la competitividad al sector de fabricación de turrón", Revista valenciana de economía y hacienda, Vol. 6 pp. 111-138.

Miller, D. (1994), "What happens after success: the perils of excellence", Journal of Management Studies, Vol. 31 No. 3, pp. 325-358.

Morris, M., Handcock, M. and Hunter D. (2008), "Specification of exponential-family random graph models: Terms and computational aspects", Journal of Statistical Software, Vol. 24 No. 4, pp. 1-24.

Morrison, A. and Rabellotti, R. (2009), "Knowledge and information networks in an Italian wine cluster", European Planning Studies, Vol. 17 No. 7, pp. 983-1006.

Mowery, D.C. and Oxley, J.E. (1995), "Inward technology transfer and competitiveness: the role of national innovation systems", Cambridge journal of economics, Vol. 19 No. 1, pp. 67-93.

Nelson, R. and Winter, S. (1982), An Evolutionary Theory of Economic Change, Harvard University Press, Cambridge.

Obstfeld, D. (2005), "Social networks, the tertius iungens orientation, and involvement in innovation", Administrative Science Quarterly, Vol. 50 No. 1, pp. 100-130

Podsakoff, P., Mackenzie, S., Lee, J. and Podsakoff, N. (2003), "Common method biases in behavioral research: A critical review of the literature and recommended remedies", Journal of applied psychology, Vol. 88 No. 5, pp. 879-896.

Podolny, J. (1993), “A status-based model of market competition”, American Journal of Sociology, Vol. 98 No. 4, pp. 829-872.

Polanyi, M. (1966), The Tacit Dimension, Routledge \& Kegan Paul, London.

Pullen, A., De Weerd-Nederhof, P., Groen, A., Song M. and Fissche, O. (2009), "Successful Patterns of Internal SME Characteristics Leading to High Overall Innovation Performance", Creativity and Innovation Management, Vol. 18 No. 3, pp. 209-223.

Rivera, M., Soderstrom, S. and Uzzi, B. (2010), "Dynamics of dyads in social networks: Assortative, Relational and Proximity Mechanisms", Annual Review of Sociology, Vol. 
36 No. 1, pp. 91-115.

Robbins, G., Snijders, T., Wang, P., Handcock, M. and Pattison, P. (2007), "Recent developments in exponential random graph (p*) models for social networks", Social Networks, Vol. 29 No. 2, pp. 192-215.

Ryall, M. and Sorenson, O. (2007), "Brokers and competitive advantage", Management Science, Vol. 53 No. 4, pp. 566-583.

Saxenian, A. (1994), Regional Advantage Culture and Competition in Silicon Valley and Route 128, Harvard University Press, Cambridge.

Shapiro, C. (1983), "Premiums for High Quality Products as Returns to Reputations", Quarterly Journal of Economics, Vol. 98 No. 4, pp. 659-680.

Sherwat, E. Ibrahim, M. Hosein Fallah and Richard R. Reilly (2006), "Do Localized Clusters Influence Creativity of Inventors?", Creativity and Innovation Management, Vol. 15 No. 4, pp. 410-418.

Stuart, T.E., Hoang, H. and Hybels, R.C. (1999), "Interorganizational Endorsements and the Performance of Entrepreneurial Ventures", Administrative Science Quarterly, Vol. 44 No. 2, pp. 315-349.

Teece, D.J. (2007), "Explicating dynamic capabilities: the nature and microfoundations of (sustainable) enterprise performance", Strategic Management Journal, Vol. 28 No. 13, pp. 1319-1350.

Ter Wal, A. (2014), "The dynamics of the inventor network in German biotechnology: geographic proximity versus triadic closure", Journal of Economic Geography, Vol. 14 No. 3, pp. 589-620.

Ter Wal, A. and Boschma, R. (2009), "Applying social network analysis in economic geography: theoretical and methodological issues", Annals of Regional Science, Vol. 43 No. 3, pp. 739-756.

Torre, A. (2008), "On the role played by temporary geographical proximity in knowledge transmission”, Regional Studies, Vol. 42 No. 6, pp. 869-889.

Triguero, A., Córcoles, D. and Cuerva, M. (2013), "Differences in innovation between food and manufacuring firms: An analysis of persistence", Agribusiness, Vol. 29 No. 3, pp. 273-292.

Van der Vegt, G., Bunderson, S. and Oosterhof, A. (2006), "Expertness diversity and interpersonal helping in teams: Why those who need the most help end up getting the least", Academy of Management Journal, Vol. 49 No. 5, pp. 877-893.

Wang, C.L. and Ahmed. P.K. (2004), "The development and validation of the organisational innovativeness construct using confirmatory factor analysis", European Journal of Innovation Management, Vol. 7 No. 4, pp. 303-313. 
Wasserman, S. and Faust, K. (1994), Social Network Analysis: Methods and Applications, Cambridge University Press, Cambridge.

Zaheer, A. and Bell, G. (2005), "Benefiting from network position: firm capabilities, structural holes and performance", Strategic Management Journal, Vol. 26 No. 9, pp. 809-825. 
Table 1. Characterisation of businesses in the Xixona foodstuffs cluster

\begin{tabular}{c|r}
\multicolumn{1}{c}{ Characteristics } & Numbers of firms \\
\hline Employees & $10(27.8 \%)$ \\
$\leq \leq 10$ & $7(19.4 \%)$ \\
$10<\mathrm{X} \leq 25$ & $10(27.8 \%)$ \\
$25<\mathrm{X} \leq 50$ & $6(16.7 \%)$ \\
$50<\mathrm{X} \leq 100$ & $3(8.35)$ \\
$100<$ & \\
Sales (thousands Euros) & $10(27.9 \%)$ \\
$\leq 1.000$ & $12(33.3 \%)$ \\
$1.000<\mathrm{X} \leq 3.000$ & $7(19.4 \%)$ \\
$3.000<\mathrm{X} \leq 6.000$ & $7(19.4 \%)$ \\
6.000< & \\
Year of creation & $15(41.7 \%)$ \\
Up to the 1970's & $4(11.1 \%)$ \\
1980 's & $10(27.8 \%)$ \\
1990 's & $7(19.4 \%)$ \\
2000 's & \\
International activity & $16(44.4 \%)$ \\
Exporter & $19(52.8 \%)$ \\
Importer & \\
Position in the value chain & $24(66.7 \%)$ \\
Manufacturers & $12(33.3 \%)$ \\
Suppliers & \\
Legal structure & $17(47.2 \%)$ \\
Public limited company & $15(41.7 \%)$ \\
Private limited company & $4(11.1 \%)$ \\
Other & \\
Membership of local institutions & $22(66.1 \%)$ \\
POD (denomination of origin) & $24(66.7 \%)$ \\
TDC (business association) & $36(100 \%)$ \\
City & \\
Xixona &
\end{tabular}

Table 2. Correlation matrix of independent variables observed

\begin{tabular}{lccccc}
\hline \multicolumn{1}{c}{ Variables } & $\mathbf{1}$ & $\mathbf{2}$ & $\mathbf{3}$ & $\mathbf{4}$ & $\mathbf{5}$ \\
\hline (1) Age & 1 & & & & \\
(2) Absorptive Capacity & -.114 & 1 & & & \\
(3) Position in the value system & $.548^{* *}$ & .262 & 1 & & \\
(4) Innovation (Ego) & .001 & -.123 & -.018 & 1 & \\
(5) Innovation (Alter) & .035 & -.107 & .043 & $.363 *$ & 1 \\
\hline $\mathrm{N}=36 * * * \mathrm{p}<.05 * \mathrm{p}<1$ & & & & &
\end{tabular}


Table 3. Descriptions of Technological and Business Networks

\begin{tabular}{ccc} 
& Technological Network & Business Network \\
\hline Density & .301 & .294 \\
Reciprocity & .684 & .635 \\
Transitivity & .434 & .452 \\
Centrality & .293 & .264 \\
\hline Dyads & 1260 & 1260 \\
Links & 389 & 370 \\
Nodes & 36 & 36 \\
\hline
\end{tabular}

Table 4. ERGM: Results for the Technological and Business Networks

\begin{tabular}{lrr}
\hline & \multicolumn{1}{c}{$\begin{array}{c}\text { Technological } \\
\text { Network }\end{array}$} & $\begin{array}{c}\text { Business } \\
\text { Network }\end{array}$ \\
\hline Density (edges) & \multicolumn{1}{c}{ B (p-value) } & B (p-value) \\
\cline { 2 - 3 } Reciprocity & $-2.720^{* * *}$ & $-2.874^{* * *}$ \\
Transitivity (1) & $.449^{* * *}$ & $.465^{* * *}$ \\
Age & -.012 & -.001 \\
Absorptive Capacity & $.088^{* *}$ & -.018 \\
Position in the value system & -.092 & -.083 \\
Innovation (Ego) & $-.120^{* *}$ & $-.222^{* * *}$ \\
Innovation (Alter) & $.191 * * *$ & $.318^{* * *}$ \\
\hline AIC & 1747 & 1713 \\
BIC & 1713 & 1754 \\
\hline $\mathrm{N}=36 ; * * \mathrm{p}<.01 * * * \mathrm{p}<.05 * * \mathrm{p}<.1$ & & \\
\hline
\end{tabular}

(1) Transitivity was measure using GWESP (1.5) 
Figure 1. Endogenous forces in the network: description and visualisation Description Visualisation

\begin{tabular}{ll}
\hline Density & $\begin{array}{l}\text { Global tendency of the } \\
\text { companies to ask for } \\
\text { information } \\
\text { Tendency for mutual } \\
\text { exchange of information }\end{array}$ \\
Transitivity & $\begin{array}{l}\text { Global tendency to closed } \\
\text { triads in the search for } \\
\text { information by companies }\end{array}$
\end{tabular}

The broken arrow shows creation of a positive relationship. The continuous arrow shows an already existing relationship

Figure 2. Visualisation of the technological and business networks

\begin{tabular}{|c|c|c|}
\hline Technological Network & Business Network \\
\hline & & \\
\hline
\end{tabular}

${ }^{1}$ Studies on clusters or industrial clusters are few and far between. Giuliani (2013) is an exception. 